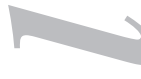

\title{
Infection with Helicobacter pylori. Prevalence, research and impact of antibiotic resistance
}

Antibiotic resistance is probably the primary cause of failed therapy for infectious disease, particularly for infection with Helicobacter pylori. Since the relevance of infection with $H$. pylori in the pathogenesis of peptic gastroduodenal disease and gastric neoplasms was unveiled, the effectiveness of treatment with a number of antibiotics and therapeutic schemes has been investigated (1). H. pylori is intrinsically resistant to glycopeptides, cefsulodin, polymyxines, nalidixic acid, trimetoprim, sulfonamides, nystatin, amphotericin B, and cycloheximide, whereas wild-type strains are susceptible to $\beta$-lactams (except cefsulodin), phosphomycin, macrolides, aminoglycosides, tetracyclines, chloramphenicol, rifampicin, fluoroquinolones, 5-nitroimidazoles, and nitrofurans (2). So-called quadruple therapy with a proton-pump inhibitor (PPI) in combination with bismuth, tetracyclines and metronidazole, and most particularly triple therapy with a PPI associated with clarithromycin and amoxicillin or metronidazole represent the most widely accepted therapies. The European Helicobacter Study Group (EHSG) reported in 1997 the conclusions of the $1^{\text {st }}$ Consensus Conference held in Maastricht, and recommended triple therapy as first-line treatment for infection with $H$. pylori, with quadruple therapy being held in reserve for potential first-line treatment failures (3). Triple therapy has remained the first-choice regimen during the past decade, and has been recommended by most consensus meetings and both European and American scientific societies (4-8). The initial effectiveness of this regimen, around $80-90 \%$, has progressively declined to below $80-70 \%$ in the last few years, which has led to consider novel therapeutic approaches (9-19). Acquired resistance to commonly-used antibiotics, particularly clarithromycin and metronidazole, is thought to be the primary cause of treatment failure, but other causes such as non-compliance or prescriptions with inadequate dosage or duration should also be taken into account (2022).

\section{Prevalence of antibiotic resistance of $\boldsymbol{H}$. pylori}

During the period 1999-2003 multiple studies were reported on the prevalence of primary antibiotic resistance in $H$. pylori, and significant variations were seen among countries or even regions and ethnic groups within countries. In Europe, a low prevalence of resistance to clarithromycin was reported in the Netherlands, Germany, and Sweden (1.7-2.9\%), which was higher in Spain, France and Portugal (12-22\%) (22-27). Interestingly, prevalence in northern Italy was 1.8 versus $23.4 \%$ in central Italy (28-29). It was 10-12\% in the United States, $25 \%$ in Mexico, in 9.8\% in Brazil, 11-13\% in Japan, and 5-6\% in Korea (30-37). The prevalence of resis- 
tance to metronidazole was 15-40\% in Europe, 20-35\% in the United States, $76 \%$ in Mexico, 53\% in Brazil, 9-12\% in Japan and 40\% in Korea, while that of resistance to amoxicillin and tetracyclines was below 1\% (22-37). A meta-analysis of 20 clinical trials in the USA acknowledges an increased prevalence of resistance to clarithromycin, from $4.9 \%$ in $1993-95$ to $10.1 \%$ in $1995-99$ (38). A multicenter European study with homogeneous methodology performed in 22 countries during 1998 found that the prevalence of primary resistance to clarithromycin was $9.9 \%$, to metronidazole was $33.1 \%$, and to amoxicillin was $0.8 \%$. Resistance to clarithromycin was more common in children versus adults, and in southern (18\%) versus central $(9.3 \%)$ or northern $(4.2 \%)$ European countries. Simultaneous resistance to clarithromycin and metronidazole was also more frequent in southern European countries (39).

A multicenter European study was carried out in 14 countries during 1999-2002 to assess $H$. pylori antibiotic resistance in the pediatric population. The prevalence of primary resistance to clarithromycin was $20 \%$, higher in younger children $(<6$ $v s .>12$ years) and in people residing in southern Europe; that of primary resistance to metronidazole was $23 \%$, to both clarithromycin and metronidazole was $5.3 \%$, and to amoxicillin was $0.6 \%$ (40).

In Spain several studies on the primary antibiotic resistance of $H$. pylori were published during 1999-2004, which revealed that the prevalence of resistance to clarithromycin ranged from 8.7 to $13 \%$, and to metronidazole from 13.8 to $42 \%$ $(26,41-44)$. In Seville, in our healthcare area, we observed that the prevalence of resistance to clarithromycin was $10 \%$, and to metronidazole was $28.6 \%$, during the period 1996-1998, consistent with previously reported data (45).

More recent publications (2006-09) show that, in the last decade, primary resistance to clarithromycin has either remained stable or increased, which would account for the progressively decreased effectiveness of triple therapy. Zullo et al., during 2004-06, identified in Italy a prevalence of primary resistance to clarithromycin of $16.9 \%$, more common in patients with non-ulcer dyspepsia (19.1\%) (46). Boyanova et al., in Bulgaria, observed a prevalence of primary resistance to clarithromycin of $10 \%$ during the period 1996-99, and of $17.9 \%$ during the period 2005-07 (47), and such an increase was also seen in other studies in Great Britain, Korea and Japan (48-50). Storskurubb et al., in Sweden, saw a low prevalence of primary resistance to clarithromycin (1.5\%) and metronidazole $(16.2 \%)$, which they relate to low use because of restrictive antibiotic policies (51). Aboderin et al. reported the opposite in Nigeria upon detection of $100 \%$ resistance to clarithromycin, ampicillin, and metronidazole in 32 study cases, which they related to uncontrolled use of these antibiotics (52). Agudo et al., in Madrid (Spain), during the period 2002-06, identified in children a high primary and secondary resistance to clarithromycin (49.2 and 70.6\%), superior to that seen with metronidazole (32.8 and $41.2 \%$ ), and dual resistance to clarithromycin and metronidazole, both primary and secondary, in 15.4 and $26.5 \%$ of cases, respectively; the authors highlighted the huge negative effect of such a high prevalence on the efficacy of triple therapy for $H$. pylori eradication (53). Kalach, during 1999-2005 in France, also detected in children a high prevalence of primary resistance to clarithromycin (23.2\%), lower than that seen in Spain and that remained stable since 1994-98 (22.1\%) (54). Antibiotic resistance and its negative influence on the effectiveness of eradicating therapies for H. pylori was a most relevant topic at the Third Maastricht Consensus Conference (6). Increased resistance to clarithromycin was endorsed in association with a greater use, and triple therapy with a PPI, amoxicillin or metronidazole, and clar- 
ithromycin was recommended for populations with resistance prevalence lower than 15-20\%, whereas clarithromycin should otherwise be withheld. Quadruple therapy with a PPI, bismuth, tetracyclines and metronidazole may be an alternative to triple therapy as first-line regimen. The impact on triple therapy effectiveness is higher in cases with resistance to clarithromycin versus resistance to metronidazole $(21,55)$. In the review by Megraud, published in 2004 (21), the effectiveness of triple therapy with a PPI, amoxicillin and clarithromycin is seen to decrease from 87.8 to $18.3 \%$ depending on sensitivity or resistance to the latter antibiotic, with a loss of efficacy at virtually $70 \%$. That study also revealed that the efficacy of triple therapy with a PPI, amoxicillin and metronidazole, depending on the presence of susceptibility or resistance to the latter antimicrobial, has decreased from 89.4 to $64.4 \%$, with a loss of efficacy at $25 \%$, and that the effectiveness of triple therapy with a PPI, clarithromycin and metronidazole has decrease from 97 to $0 \%$, according to susceptibility or resistance to both antibiotics, with an efficacy of $72.6 \%$ in case of clarithromycin susceptibility and metronidazole resistance, and of 50\% in the opposite situation. It is thought that treatment for $H$. pylori infection should be recommended when efficacy is higher than $80 \%$ (intention-to-treat) or $85 \%$ (per protocol $)(3,11,56)$. The current effectiveness of triple therapy as first-choice regimen is usually below $80 \%$, even $70 \%$ in some studies (9-12), and cannot be therefore recommended.

\section{Mechanisms of antibiotic resistance in $\mathrm{H}$. pylori}

Evidence suggests that the mechanisms of antimicrobial resistance in $H$. pylori mainly result from chromosomal mutations $(22,57)$ primarily acquired through vertical transmission among bacteria. Chromosomal mutations will show up in the offspring, which will consequently lead to a progressive increase in the prevalence of antimicrobial resistance. Horizontal transference from a resistant to a susceptible strain, both of them in the stomach, cannot be ruled out.

Clarithromycin is a bacteriostatic antibiotic; a semisynthetic derivative of erythromycin, it belongs in the macrolide class, and is the most powerful drug against $H$. pylori. It targets ribosomes, thereby blocking bacterial protein synthesis. Resistance to clarithromycin results from point mutations that occur in the 23S rRNA gene and modify ribosome structure, impairing antibiotic binding. Most common mutations include adenine replacement by cytosine or guanine at position 2142 (A2142C, A2142G), or by guanine at position 2143 (A2143G); A2115G and G2141A occur less commonly. These mutations enable resistant strains to tolerate increasing antibiotic concentrations, from 1 to $64 \mu \mathrm{g} / \mathrm{mL}(58,59)$.

Amoxicillin is a bactericidal antibiotic inhibiting bacterial wall synthesis. The prevalence of $H$. pylori resistance to amoxicillin is very low, and this antibiotic requires the presence of penicillin-binding proteins (PBPs) for proper functioning. The mechanism of resistance generated by $H$. pylori consists of mutations in gene $p b p$ that result in changed PBPs with greater antibiotic affinity. Resistant strains do not generate amoxicillin-PBP complexes, and thus preclude bactericidal effects (57).

Tetracyclines are bacteriostatic antibiotics that target ribosomes to block bacterial protein synthesis. The prevalence of resistance to tetracyclines in H.pylori is very low, and is acquired via mutations in the $16 \mathrm{~S}$ rRNA gene, primarily in adenine-guanine-adenine triplets at positions 926 to 928 (AGA 926-928); single, dual or even 
triple substitutions may occur. A triple replacement of AGA926-928 by thymine, thymine and cytosine, respectively (AGA926-928 $\rightarrow$ TTC), in the $16 \mathrm{~S}$ rRNA gene enables strains to tolerate antibiotic concentrations up to $64 \mu \mathrm{g} / \mathrm{mL}$; dual mutations allow the tolerance of concentrations up to $8 \mu \mathrm{g} / \mathrm{mL}$, and single replacements enable tolerance to $2 \mu \mathrm{g} / \mathrm{mL}(60,61)$. The presence of other potential mechanisms of resistance has been discussed in recent years, involving either TetA efflux protein (62) or the presence of a membrane permeability inhibitor.

Metronidazole is a bactericidal antibiotic within the nitroimidazole class that has been widely and indiscrimanetely used in the management of multiple infections, thus conditioning a high prevalence of resistance in $H$. pylori. Nitroimidazoles, on entering target cells, are activated via a reduction process mediated by the enzyme NADPH-nitroreductase, which damages DNA and bacterial structures. The mechanisms of resistance currently known are based on mutations in genes $r d x A$ and $f r x A$, which would block cell-related nitroimidazole activation.

Levofloxacin and ciprofloxacin are bactericidal antibiotics in the quinolone class; their mechanism of action is similar and consists of blocking bacterial DNA replication by binding the enzyme DNA-gyrase, coded for by genes gyrA and gyrB. $H$. pylori resistance to these antibiotics is conditioned by mutations in gyrA QRDR (quinolone resistance-determining region) (63).

\section{Methods for the study of $\boldsymbol{H}$. pylori antibiotic susceptibility}

Multiple methods are available for the study of $H$.pylori antibiotic susceptibility, which may be categorized as phenotypical methods, most commonly used and based on gastric biopsy cultures, including agar dilution and E-test (epsilometer test), and genotypical methods, including fluorescent in situ hybridation, PCR (polymerase chain reaction), both conventional and with sequencing, RFLP (restriction fragment length polymorphism) PCR, and real-time PCR, which allows to directly detect chromosomal mutations in gastric biopsies and feces. The Clinical and Laboratory Standards Institute (CLSI), formerly the National Committee for Clinical Laboratory Standards (NCCLS), recommends agar dilution as gold standard for the study of $H$. pylori susceptibility to antibiotics, specifically for minimum inhibitory concentration (MIC) estimates, and establishes cutoff points for clarithromycin (64). The British Society for Antimicrobial Chemotherapy (BSAC) recommends in turn E-test diffusion, which has a high correlation with agar dilution. E-test has the benefit of being a quantitative method with direct MIC expression; it also adapts to slow-growing bacteria such as $H$. pylori (65). Other available methods include broth dilution and disk diffusion $(66,67)$. Cutoff points suggested for clarithromycin include: $\leq 0.25 \mu \mathrm{g} / \mathrm{mL}$ for susceptible strains, $\geq 1 \mu \mathrm{g} / \mathrm{mL}$ for resistant strains, and $0,5 \mu \mathrm{g} / \mathrm{mL}$ for intermediate strains. These cutoffs have allowed excellent predicting values for the success of triple therapy with a PPI, clarithromycin and amoxicillin. No standardized criteria are available for antibiotics, including amoxicillin, tetracyclines, rifabutin, and levofloxacin. However, agar dilution may be used, and literature-endorsed cutoff points are used $(47,68)$. Metronidazole is special in that most studies have shown an absence of interlab and intralab reproducibility on unknown grounds (2). Absent correlation between H. pylori susceptibility and eradicating therapy outcomes should also be counted in. H. pylori strains with a high MIC may be eradicated, possibly due to a variable redox potential within the stomach. The cutoff point usually considered to define resistance to metron- 
idazole is $\geq 8 \mu \mathrm{g} / \mathrm{mL}$. EHSG, at the $3^{\text {rd }}$ Maastricht Consensus Conference, discourages the use of metronidazole susceptibility tests in clinical practice for want of clinico-bacteriological correlation (6).

Genotypical methods are particularly used for the study of clarithromycin resistance, but may also be applied for other antibiotics. Chromosomal mutations responsible for antibiotic resistance may be easily detected with molecular testing based on fluorescent in situ hybridation (69) or genomic amplification, mainly using PCR-related techniques (22). The advantages of such molecular tests include a shorter time for results, and an excellent correlation with susceptibility as assessed using phenotypical methods. Their main shortcoming is that they require a molecular microbiology laboratory. The first genotypical method used was RFLP PCR. This test amplifies the region harboring mutations, and synthesized fragments are then treated with restriction endonucleases that recognize specific mutation-generated sites. The size of the resulting fragments indicates the presence or absence of a mutation (22). RFLP PCR is a simple method but uses conventional PCR, which delays results and requires amplicon manipulation because of contamination risks. PCR with subsequent amplified fragment sequencing has been used on gastric bacteria and biopsies to assess resistance to clarithromycin and quinolones. It may also be used for other antibiotics such as amoxicillin. The technique is somewhat complex but automation has allowed its development (22). Lastly, real-time PCR has been successfully used $(22,70)$ to detect any mutations in the amplified region, and represents a relevant advance as results may be obtained within 2 hours. It has been used to directly identify $H$. pylori in biopsy and fecal samples, as well as in cultured bacteria. Real-time PCR for fecal samples has become a promising diagnostic technique as it represents a rapid, non-invasive method allowing direct bacterial identification and an assessment of clarithromycin susceptibility. A higher degree of standardization demands a commercially available kit with high sensitivity and specificity.

The study by Torres Debat et al. included in this issue of the Spanish Journal of Gastroenterology (71) is first to inform on the prevalence of $H$. pylori antibiotic resistance in Uruguay, and also investigates the molecular mechanisms of clarithromycin resistance using PCR. The authors research the prevalence of antibiotic resistance using the E-test in two time periods and two adult populations with gastric biopsy cultures positive for H. pylori, and diverse ethnic descent. In 2001 they studied 19 patients representative of the general population, and in 2006 they studied 31 patients of African descent. The prevalence of resistance to metronidazole was 36.8 and $35.5 \%$, respectively; to clarithromycin, 0 and $19.4 \%$; to levofloxacin, 5.2 and 3.2\%; and to amoxicillin and tetracyclines, $0 \%$ for both groups. Of note is the variable prevalence of clarithromycin resistance in these two periods of time and/or population groups. The fact that antibiotic - and specifically clarithromycin resistance prevalence varies among countries or among regions, social groups, or ethnic groups within one same country is well known. Information available on antibiotic resistance prevalence in African populations or Latin American countries is insufficient. In Mexico, during the years 1995-97, the prevalence reported for clarithromycin resistance was $25 \%$ (32); recently, a prevalence of $2 \%$ was acknowledged in Paraguay (72). Aboderin, during the period 2002-06 in Nigeria, detected a $100 \%$ prevalence of clarithromycin resistance, and that for other antibiotics was also very high (52). Available data are anyway inadequate for drawing conclusions. The prevalence of clarithromycin resistance found in 2006 by Torres Debat et al. in Uruguay is high, and these authors also state that whether this reflects the current 
status in the general population, with a rapid increase during the last few years, or the current status in a specific Uruguayan ethnic group is uncertain, the latter possibility being potentially supported by the finding of one single mutation at position 2143 in all cases (71). The high prevalence of resistance to metronidazole is similar to that currently seen in some developed rather than - as claimed by the authors developing countries (39).

As previously stated, it is accepted that triple therapy should not be used to manage $H$. pylori infection when the prevalence of clarithromycin resistance is higher than $15-20 \%$, as in the above study; in such cases other therapeutic alternatives should be considered. It would be desirable to have regularly updated, reliable information on the prevalence of antibiotic resistance in H.pylori, specifically regarding clarithromycin, for the various countries, regions or healthcare areas, so that the potentially most effective eradicating regimen could be assessed on an individual basis. The study of antibiotic resistance is particularly necessary when low effectiveness is found regarding triple therapy for $H$. pylori eradication, and in certain patients following the failure of an initial or second eradicating therapy.

\title{
M. Castro-Fernández and J. Vargas-Romero ${ }^{1}$
}

\author{
Unit of Clinical Management of Digestives Diseases and ${ }^{\prime}$ Clinical Management of \\ Microbiology. CIBERehd. Hospital Universitario de Valme. Sevilla, Spain
}

\section{REFERENCES}

1. Gisbert JP, Pajares R, Pajares JM. Evolution of Helicobacter pylori therapy from a meta-analytical perpective. Helicobacter 2007; 12(Supl. 2): 50-8

2. Lambert, T, Megraud F, Gerbaud G, Courvalin P. Susceptibility of Campylobacter pyloridis to 20 antimicrobial agents. Antimicrob Agents Chemother 1986; 30: 510-1.

3. The European Helicobacter pylori Study Group (EHPSG). Current European concepts in the management of Helicobacter pylori infection: the Maastricht Consensus Report. Gut 1997; 41: 8-13.

4. Monés J, Gisbert JP, Borda F, Domínguez-Muñoz E, y Grupo Conferencia Española de Consenso sobre Helicobacter pylori. Indications, diagnostic test and Helicobacter pylori eradication therapy. Recommendations by the 2nd Spanish Consensus Conference. Rev Esp Enferm Dig 2005; 97: 348-74.

5. Gisbert JP, Calvet X, Gomollón F, Monés J, y Grupo Conferencia Española de Consenso sobre Helicobacter pylori. Tratamiento erradicador de Helicobacter pylori. Recomendaciones de la II Conferencia Española de Consenso. Med Clin (Barc) 2005; 125: 301-16.

6. Malfertheiner P, Megraud F, O’ Morain C, Bazzoli F, El-Omar E, Graham D, et al., The European Helicobacter Study Group (EHSG). Current concepts in the management of Helicobacter pylori infection: the Maastricht III Consensus Report. Gut 2007; 56: 772-81.

7. Caselli M, Zullo A, Maconi G, Parente F, Alvisi V, Casetti T, et al., the Working Group of the Cervia II Meeting. "Cervia II Working Group Report 2006": Guidelines on diagnosis and treatment of Helicobacter pylori infection in Italy. Dig Liver Dis 2007; 39: 782-9.

8. Chey WD, Wong BCY, and the Practice Parameters Committee of the American College of Gastroenterology. American College of Gastroenterology Guideline on the Management of the Helicobacter pylori Infection. Am J Gastroenterol 2007; 102: 1808-25.

9. Egan BJ, Marzio L, O'Connor H, O’Morain C. Treatment of Helicobacter pylori infection. Helicobacter 2008; 13(Supl. 1): 35-40.

10. Vakil N, Megraud F. Eradication therapy for Helicobacter pylori. Gastroenterology 2007; 133: 985-1001.

11. Graham DY, Lu H, Yamaoka. Therapy for Helicobacter pylori infection can be improved. Drugs 2008; 68: 725-36.

12. Boixeda D, Martín de Argila C, Bermejo F, López San Román A, Hernández Ranz F, Gracía Plaza A. sevenday protom pump inhibitor, amoxicillin and clarithromycin triole therapy. Factors that influence Helicobacter pylori eradication success. Rev Esp Enferm Dig 2003; 95: 202-5.

13. Calvet X, Ducons J, Bujanda L, Bory F, Montserrat A, Gisbert JP, HP Study Group ot the Asociación Española de Gastroenterología. Seven versus ten days of rabeprazole triple therapy for Helicobacter pylori eradication: a multicenter randomized trial. Am J Gastroenterol 2005; 100: 1696-701.

14. Gisbert JP, González L, Calvet X, García N, López, Roque M, et al. Protom pump inhibitor, clarithromycin an either amoxycillin or nitrimidazole. A meta-analysis of eradication of Helicobacter pylori. Aliment Pharmacol Ther 2000; 14: 1319-28. 
15. Antos D, Schneider-Brachert W, Bästlein E, Hänel C, Haferland C, Buchner M, et al. 7-day triple therapy of Helicobacter pylori infection with levofloxacin, amoxicillin, and high-dose esomeprazole in patients with know antimicrobial sensitivity. Helicobacter 2006; 11: 39-45.

16. Nista E, Candelli M, Zocco MA, Cremonini F, Ojetti V, Finizio R, et al. Levofloxacin-based triple therapy in first-line treatment for Helicobacter pylori eradication. Am J Gastroenterol 2006; 101: 1985-90.

17. Gisbert JP, Fernández-Bermejo M, Molina-Infante M, Pérez-Gallardo B, Prieto-Bermejo AB, Mateos-Rodríguez JM, et al. Levofloxacin, amoxicillin, and omeprazole as first-line triple therapy for Helicobacter pylori eradication. J Clin Gastroenterol 2009; 43(4): 384-5.

18. Castro-Fernández M, Lamas E, Pérez-Pastor A, Pabón M, Aparcero R, Vargas-Romero J et al. Efficacy of triple therapy with a proton pump inhibitor, levofloxacin, and amoxicillin as first-line treatment to eradicate Helicobacter pylori. Rev Esp Enferm Dig 2009; 101: 395-402.

19. Sánchez Delgado J, Calvet X, Bujanda L, Gisbert JP, Titó L, Castro M. Ten-day sequential treatment for Helicobacter pylori eradication in clinical practice. Am J Gastroenterol 2008; 103: 2220-3.

20. Pajares García JM, Pajares-Villarroya R, Gisbert JP. Helicobacter pylori infection: antibiotic resistence. Rev Esp Enfer Dig 2007; 99: 63-70.

21. Megraud F. H. pylori antibiotic resistance: prevalence, importance, and advances in testing. Gut 2004; 53: 1374-84.

22. Megraud F, Lehours P. Helicobacter pylori detection and antimicrobial susceptibility testing. Clin Microbiol Rev 2007; 20: 280-322.

23. Debets-Ossenkopp YJ, Herscheid A, Pot RGJ, Kuipers EJ, Kusters JG, Vandenbroucke-Grauls CMJE. Prevalence of Helicobacter pylori resistance to metronidazol, clarithromycin, amoxicillin, tetracycline and trovafloxacin in The Netherlands. J Antimicrob Chemother 1999; 43: 511-5.

24. Wolle K, Leodolter A, Malfertheimer P, König W. Antibiotic susceptibility of Helicobacter pylori in Germany: stable primary resistance from 1995 to 2000. J Med Microbiol 2002; 51: 705-9.

25. Megraud F, Lehn N, Lind T, Bayerdörffer E, O'Morain C, Spiller R, et al. Antimicrobial susceptibility testing of Helicobacter pylori in a large multicentre trial: the MACH 2 study. Antimicrob Agents Chemother 1999; 43: 2747-52.

26. Cuchí Burgos E, Forné Bardera M, Quintana Riera S, Lite Lite J, Garau Alemany J. Evolution of the sensitivity of 235 strains of Helicobacter pylori from 1995 to 1998 and impact of antibiotic treatment. Enferm Infecc Microbiol Clin 2002; 20: 157-60.

27. Cabrita J, Oleastro M, Matos R, Mantente A, Cabral J, Barros R, et al. Features and trends in Helicobacter pylori antibiotic resistance in Lisbon area, Portugal (1990-1999). J Antimicrob Chemother 2000; 46: 1029-31.

28. Toracchio S, Marzio L. Primary and secondary antibiotic resistance of Helicobacter pylori strains isolated in central Italy during the years 1998-2002. Dig Liver Dis 2003; 35: 541-5.

29. Pilotto A, Rassu M, Leandro G, Franceschi M, Di Mario F. Prevalence of Helicobacter pylori resistance to antibiotics in Northeast Italy: a multicentre study. GISU Interdisciplinary Group for the Study of Ulcer. Dig Liver Dis 2000; 32: 763-8.

30. Laine L, Fennerty MB, Osato M, Sugg J, Suchower L, Probst P, et al. Esomeprazole-based Helicobacter pylori eradication therapy and the effect of antibiotic resistance : results of three US multicentre, doubled-blind trials. Am J Gastroenterol 2000; 95: 3393-8

31. Osato MS, Reddy R, Reddy SG, Penland RL, Malaty HM, Graham, DY, et al. Pattern of primary resistance of Helicobacter pylori to metronidazol or clarithromycin in the United States. Arch Intern Med 2001; 161: 1217-20.

32. Torres J, Camorlinga-Ponce M, Pérez-Pérez G, Madrazo-de la Garza A, Dehesa M, González-Valencia G, et al. Increasing multidrug resistance in Helicobacter pylori strains isolated from children and adults in Mexico. J Clin Microbiol 2001; 39: 2677-80.

33. Prazeres Magalhaes P, de Magalhaaes Queiroz DM, Campos Barbosa DV, Aguilar Rocha G, Nogueira Mendes E, Santos A, et al. Helicobacter pylori primary resistance to metronidazol and clarithromycin in Brazil. Antimicrob Agents Chemother 2002; 46: 2021-3.

34. Perez Aldana L, Kato M, Nakagawa S, Kawarasaki M, Nagasako T, Mizushima T, et al. The relationship between consumption of antimicrobial agents and the prevalence of primary Helicobacter pylori resistance. Helicobacter 2002; 7: 306-9.

35. Kato M, Yamaoka Y, Kim JJ, Reddy R, Asaka M, Kashima K, et al. Regional differences in metronidazole resistance and increasing clarithromycin resistance among Helicobacter pylori isolates from Japan. Antimicrob Agents Chemother 2000; 44: 2214-6.

36. Kim JJ, Reddy R, Lee M, Kim JM, Osato MS, Graham DY, et al. Analysis of metronidazole, clarithromycin and tetracycline resistance of Helicobacter pylori isolates from Korea. J Antimicrob Chemother 2001; 47: 459-61.

37. Eun CS, Han DS, Park JY, Jeon YC, Hahm JS, Kim KS, et al. Changing pattern of antimicrobial resistance of Helicobacter pylori in Korean patients with peptic ulcer diseases. J Gastroenterol 2003; 38: 436-41.

38. Meyer JM, Silliman NP, Wang W, Siepman NY, Suggs JE, Morris D, et al. Risk factors for Helicobacter pylori resistance in the United States: the surveillance of $\mathrm{H}$. pylori antimicrobial resistance partnership (SHARP) STUDY, 1993-1999. Ann Intern Med 2002; 136: 13-24.

39. Glupczynski Y, Megraud F, López-Brea M, Andersen LP. European multicentre survey of in vitro antimicrobial resistance in Helicobacter pylori. Eur J Clin Microbiol Infect Dis 2001; 20: 820-3.

40. Koletzko S, Richy F, Bontems P, Crome J, Kalach N, Monteiro ML, et al. Prospective multicentre study on antibiotic resistance of Helicobacter pylori strains obtained from children living in Europe. Gut 2006; 55: 1 711-6.

41. Rojas Feria M, Suárez Barrenechea AI, Conejo Gonzalo C, Hergueta Delgado P, Romero Castro R, Herrerías Gutiérrez JM. Resistance of Helicobacter pylori to antimicrobial treatment in a Seville hospital catchment area. Rev Esp Enferm Dig 2000; 92: 793-8.

42. Toro C, García-Samaniego J, Carbó J, Iñiguez A, Alarcón T, López-Brea M, et al. Prevalence of primary He- 
licobacter pylori resistance to eight antimicrobial agents in a hospital in Madrid. Rev Esp Quimioter 2001; 14: 172-6.

43. Ferrero M, Ducóns JA, Sicilia B, Santolaria S, Sierra E, Gomollón F. Factors affecting the variation in antibiotic resistance of Helicobacter pylori over a 3-year period. Int J Antimicrob Agents 2000; 16: 245-8.

44. Gomollón F, Santolaria S, Sicilia B, Ferrero M, Revillo MJ, Ducóns J, et al. Resistencia de Helicobacter pylori al metronidazol y a la claritromicina: análisis descriptivo entre 1997 y 2000. Med Clin (Barc) 2004; 123: 481-5.

45. García Díaz E, Romero Gómez M, Vargas J, Guil A, Bernal S, Castro M. Prevalence and clinical significance of antibiotic resistance in Helicobacter pylori. Rev Esp Enferm Dig 2000; 92: 656-60.

46. Zullo A, Perna F, Hassan C, Ricci C, Saracino I, Morini S, et al. Primary antibiotic resistance in Helicobacter pylori strains isolated in northern and central Italy. Aliment Pharmacol Ther 2007; 25: 1429-34.

47. Boyanova L, Gergova G, Nikolov R, Davidkov L, Kamburov V, Jelev C, et al. Prevalence and evolution of Helicobacter pylori resistance to 6 antibacterial agents over 12 years and correlation between susceptibility testing methods. Diagn Microbiol Infect Dis 2008; 60: 409-15

48. Chisholm SA, Teare EL, Davies K, Owen RJ. Surveillance of primary antibiotic resistance of Helicobacter pylori at centres in England and Wales over a six-year period (2000-2005). Eur Surveill 2007; 12: E3-4.

49. Bang SY, Han DS, Eun CS, Kim JE, Ahn SB, Sohn JH, et al. Changing patterns of antibiotic resistance of Helicobacter pylori in patients with peptic ulcer disease. Korean J Gastroenterol 2007; 50: 356-62.

50. Kobayashi I, Murakami K, Kato M, Kato S, Azuma T, Takahashi S, et al. Changing antimicrobial susceptibility epidemiology of Helicobacter pylori strains in Japan between 2002 and 2005. J Clin Microbiol 2007; 45: 4006-10.

51. Storskrubb T, Aro P, Ronkainen J, Wreiber KK, Nyhlin H, Bolling-Sternevald E, et al. Antimicrobial susceptibility of Helicobacter pylori strains in a randon adult Swedish population. Helicobacter 2006; 11: 224- 30.

52. Aboderin OA, Abdu AR, Odetoyin B, Oneke IN, Lawal OO, Ndububa DA, et al. Antibiotic resistance of Helicobacter pylori from patients in Ife-Ife, South-west, Nigeria. Afr Health Sci 2007; 7: 143-7.

53. Agudo S, Alarcón T, Cibrelus L, Urruzuno P, Martínez MJ, López-Brea M. High percentage of clarithromycin and metronidazole resistence in Helicobacter pylori isolates obtained from Spanish children. Rev Esp Quimioter 2009; 22: 88-92.

54. Kalach N, Serhal L, Asmar E, Campeotto F, Bergeret M, Dehecq E, et al. Helicobacter pylori primary resistant straints over 11 years in French children. Diagn Microbiol Infect Dis 2007; 59: 217-22.

55. Fischbach L, Evans EL. Meta-analysis: the effect of antibiotic resistance status on the efficacy of triple and quadruple first-line therapies for Helicobacter pylori. Aliment Pharmacol Ther 2007; 26: 343-57.

56. Graham DY, Lu H, Yamaoka Y. A report to grade Helicobacter pylori therapy. Helicobacter 2007; 12: 275-8.

57. Gerrits MM, Van Vliet AHM, Kuipers EJ, Kusters JG. Helicobacter pylori and antimicrobial resistance: molecular mechanisms and clinical implications. Lancet Infect Dis 2006; 6: 699-709.

58. Versalovic J, Shortridge D, Kibler K, Griffy MV, Beyer J, Flamm RK, et al. Mutations in 23S rRNA are associated with clarithromycin resistance in Helicobacter pylori. Antimicrob Agents Chemother 1996; 40: 477-80.

59. Occhialini A, Urdaci M, Doucet-Populaire F, Bebear CM, Lamouliatte H, Megraud F. Macrolide resistance in Helicobacter pylori: rapid detection of point mutations and assays of macrolide binding to ribosomes. Antimicrob Agents Chemother 1997; 41: 2724-8.

60. Trieber CA, Taylor DE. Mutations in the $16 \mathrm{~S}$ rRNA genes of Helicobacter pylori mediate resistance to tetracycline. J Bacteriol 2002; 184: 2131-40.

61. Dailidiene D, Bertoli MT, Miciuleviciene J, Mukhopadhyay AK, Dailide G, Pascasio MA, et al. Emergence of tetracycline resistance in Helicobacter pylori: multiple mutational changes in $16 \mathrm{~S}$ ribosomal DNA and other genetic loci. Antimicrob Agents Chemother 2002; 46: 3940-6.

62. Li Y, Dannelly HK. Inactivation of the putative tetracycline resistance gene HP1165 in Helicobacter pylori led to loss of inducible tetracycline resistance. Arch Microbiol 2006; 185: 255-62.

63. Bogaerts P, Berhin C, Nizet H, Glupczynski Y. Prevalence and mechanisms of resistance to fluoroquinolones in Helicobacter pylori strains from patients living in Belgium. Helicobacter 2006; 11: 441-5.

64. Clinical and Laboratory Standard Institute. Performance standards for antimicrobial susceptibility testing. Nineteenth informational supplement M100-S19. Clinical and Laboratory Standard Institute, Wayne, Pennsylvania, USA, January 2009; 29: 91.

65. Glupczynski Y, Broutet N, Cantagrel A, Andersen LP, Alarcón T, Lopez Brea M, et al. Comparison of the E test and agar dilution method for antimicrobial suceptibility testing of Helicobacter pylori. Eur J Clin Microbiol Infect Dis 2002; 21: 549-52.

66. Sisto F, Maddalena M, Russello G, Bonomi A, Dubini F. Antimicrobial susceptibility testing of Helicobacter pylori determined by microdilution method using a new medium. Curr Microbiol 2009; 58: 559-63.

67. Grignon B, Tankovic J, Megraud F, Glupczynski Y, Husson MO, Conroy MC, et al. Validation of diffusion methods for macrolide susceptibility testing of Helicobacter pylori. Microb Drug Resist 2002; 8: 61-6.

68. Wu H, Shi XD, Wang HT, Liu JX. Resistance of Helicobacter pylori to metronidazole, tetracycline and amoxycillin. J Antimicrob Chemother 2000; 46: 121-3.

69. Vega AE, Alarcón T, Domingo D, López-Brea M. Detection of clarithromycin-resistant Helicobacter pylori in frozen gastric biopsies from pediatric patients by a commercially available fluorescent in situ hybridization. Diagn Microbiol Infect Dis 2007; 59(4): 421-3.

70. Oleastro M, Menard A, Santos A, Lamouliatte H, Monteiro L, Barthelemy P, et al. Real-time PCR assay for rapid and accurate detection of point mutations conferring resistance to clarithromycin in Helicobacter pylori. J Clin Microbiol 2003; 41: 397-402.

71. Torres Debat ME, Pérez Pérez G, Olivares A, Fernández L, Raisler K, Gonzalez N, et al. Antimicrobial susceptibility of Helicobacter pylori and mechanisms of clarithromycin resistence in straints isolated from patients in Uruguay. Rev Esp Enferm Dig 2009; 101: 757-62.

72. Fariña N, Kasamatsu E, Samudio M, Morán M, Sanabria R, Laspina F. Antimicrobial susceptibility of H. pylori straints obtained from Paraguayan patients. Rev Med Chil 2007; 135: 1009-14. 